* Corresponding author Phone +42155602222 E-mail address:dusan.knezo@tuke.sk (prof. RNDr. Dušan Knežo, CSc)

Article information Article history: AMS-Volume16-No.1-00139-12 Received 15 January 2012 Accepted 15 March 2012

\section{Experimental Analysis of the Effect of Cutting Conditions on Microgeometry of the Machined Surface}

\author{
Miroslav Badida a* , Miroslav Gombár b , Lýdia Sobotová a , Ján Kmec ${ }^{\text {b }}$ \\ Alena Vagaskáb
}

a Department of Environmental Studies and Process Controlt, Faculty of Mechanical Engineering, Park Komenského 5, 04200 Košice, Slovak Republic

${ }^{b}$ Presov University of Prešov, Faculty of Management, Konštantínova 16, 080 0I Prešov

\section{BIOGRAPHICAL NOTES}

Dr.h.c. prof. Ing. Miroslav Badida, PhD. He is a graduate of Mechanical Faculty of Technical University of Košice. His scientific and research work focuses on the field of environmental engineering. An accent is put on the issue of environmental management systems, ecologization of products and their production and life cycle analysis of products. Lately his attention is paid on research in the field of physical factors of working and living environment.

Ing. Miroslav Gombár, PhD. graduated from the Technical University of Košice in 2002 where he studied at the Faculty of Manufacturing Technologies. Nowadays he is a director of the private company dealing with the coating services of metals, aluminium and its alloys. From 2004 to present time he was educated at the University of Prešov in Prešov and at the Technical University of Košice, i.e. at the Faculty of Manufacturing Technologies with a seat in Prešov. On the present time he has been educated at the Faculty of Management. In parallel he has been interested in practical engineering, especially in the chemical and electrochemical surface treatment. In the field of scientific research he is primarily focused on the issue of research and optimization of factors affecting during the individual technologies of electrochemical processes for surface treatment, mostly in anodic oxidation of aluminium and its alloys. In addition he deals with applications of mathematical-statistical methods and methodology of Design of Experiments (DoE) in the field of mechanical engineering technologies and surface treatment of materials.

The results of his scientific-research activities have been published in 6 monographs, in some university textbooks and scientific publications. He has published over 100 scientific articles in domestic and international journals, in scientific conference proceedings and has participated in several grant projects and engineering works as author and co-author.

doc. Ing. Lýdia Sobotová, PhD. is a docent on Technical University in Košice, Faculty of Mechanical Engineering. She graduated at the Faculty of Mechanical Engineering, VŠT Košice in 1983. She received her PhD. Degree from Technical University in Košice in 1992. Her scientific focus is oriented to metal forming, material testing, thermal drilling and progressive mechanical technologies. Today Mrs. Sobotová is an associated professor at the Faculty of Mechanical Engineering and is a member of the Department of Technologies and Materials. She is a co-author of academic textbooks. She has published more than 140 publications in home and foreign journals and conference proceedings. She was also incorporated in various grant research projects and industrial projects. 
doc. Ing. Ján Kmec, CSc. graduated in the Faculty of Mechanical Engineering, VŠT in Košice, in 1977. At present, he is associate professor at the Department of Technologies and Materials, the Faculty of Mechanical Engineering, TU in Košice. He introduced new technology of water jet cutting as a head designer. He worked in firms as VUKOV Prešov, MVVZ ROBOT Prešov a WATING Prešov since 1981 to 2099. His main research interests are problem of research and optimisation of cutting parameters in the frame of energy - jet progressive technologies.

Results of research were published in 2 monographs, in more university text books and scientific publications. He published in more than 100 in home and foreign journals and scientific conferences. He participated as author and co-author in many projects and engineering works.

PaedDr. Alena Vagaská, PhD. graduated with honours from the P. J. Šafárik University in Košice in 1993 (specialization: mathematics - techniques). She passed the rigorous examination and graduated the doctoral studies at the Faculty of Natural Sciences, Constantine the Philosopher University in Nitra. Since 1995 she has educated at the Faculty of Manufacturing Technologies with a seat in Prešov, Technical University of Košice. Her scientificresearch activities are aimed at mathematical modelling of technological processes, statistical analysis of experimentally obtained data, the differential equations theory and their applications. The results of her research activities have been presented at many conferences and published in domestic and international journals (over 90 items). She is a co-author of 2 utility models, 3 monographs, several university textbooks and author of 3 chapters in scientific monographs published abroad. She has participated in many scientific projects granted by VEGA as well as in projects funded from structural funds of the EU.

\section{KEY WORDS}

Design of Experiments, feed, cutting speed, depth of cut

\section{ABSTRACT}

TMachining belongs to the basic and permanent manufacturing technology also on the present time, despite there was an idea (theoretical considering) in the publications of many experts in moulding and casting at the turn of the 70th and
80 years, that the machining could be replaced for the most part by accurate methods of casting or moulding. Although the material losses have been reduced in recent years due to approaching of components'size prepared by moulding or casting to the size desired by technical drawing, it is not possible to achieve the required accuracy of dimensions and shapes. The paper deals with statistical methods application to the evaluation of the maximum height surface roughness profile $\mathrm{Rz}$ and mean height surface roughness profile $\mathrm{Ra}$ in relation to the feed, cutting speed and depth of cut in longitudinal turning of steel C45. The main part of the paper is to demonstrate the procedure of statistical processing of experimentally obtained data in order to create a prediction model and compare it with the theoretical calculation formulas.

\section{Introduction}

WEven at present, machining is one of the essential and permanent parts manufacturing technologies despite the fact that at the turn of the 1970s and 1980s many experts in their publications on moulding and casting were theoretically considering that a prevailing part of machining processes could be replaced by methods of precise casting or moulding. Although in recent years the material loss has been significantly reduced as the parts dimensions prepared by moulding or casting approached the dimensions that are required by drawings, it is not possible to achieve such a required accuracy in dimensions and shapes as with machining[1,2,3].

When assessing the role of machining in engineering production, its significant properties are versatility and flexibility. The versatility is based on the fact that in engineering practice there are materials that cannot be moulded or welded. Practically, there is no engineering/technical material which cannot be machined at all. Its flexibility, in turn, lies in the fact that by a simple tool and a controlled movement of both a tool and a workpiece complex shapes of parts can be machined $[4,5]$.

The main task of machining technology is to ensure optimal utilisation of manufacturing techniques, automated and conventional machine tools, to use efficient tool materials and advanced tools designs with optimal cutting conditions. Optimal use of modern manufacturing techniques consists in providing a comprehensive means for 
a cutting process and ensuring basic quality requirements of the workpiece $[6,7]$. Optimal cutting conditions are set in order to achieve maximum ef ficiency and manufacturing effectiveness [9]. The surface quality, dimensional and shape accuracy, efficiency, stock removal rate and production costs are primarily dependent on the input data of the cutting process relating to a workpiece: (material, machinability, shape, surface quality), operating conditions (feed, cutting speed, depth of cut), a tool (a kind of tool sharpening, durability) and a machine $[10,11]$.

- Title of paper, authors, affiliations, key words and abstract, (emphasize corresponding author).

\section{- Introduction, including work aims.}

- Description of experimental methods and used material.

- Results and discussion of achieved results.

- Conclusion.

- Acknowledgement (if any).

- References.

\section{Description of Problem Formulation}

The Ensuring the reliability of machinery and mechanical equipment evokes the role of monitoring, evaluating and using knowledge about a real surface roughness as this will increase the quality and effectiveness of machine parts. Still, however, there are new demands on a more complete and more accurate description of the shape of the formed surface profile. The importance of an adequate surface is manifested where the interrelationship of functional areas significantly affects the development of a certain physical process. When defining and optimizing the functional areas system, it is necessary to consider surfaces of the functional areas and their corresponding characteristics. The relationship between the function and the quality of the surface area, which is created by a certain technological method, can be evaluated from two aspects. The first aspect is the spatial arrangement of the surface, which is expressed mainly by its roughness. The second one is physical and chemical properties of a surface layer of machine parts. The effect on the mentioned properties caused by the manufacturing methods in relation to the function can be expressed by the definition of surface integrity. Integrity involves the conditions under which a functional surface occurs, the effects of technological methods and their influence on the properties of the newly formed surfaces and it provides their relationship with the functional requirements of the product $[12,13]$.

\section{Generation and Status of Machined Surface}

The generation and status of the machined surface are the two interrelated fields that explain the sequence of events associated with chips formation and subsequent formation of a surface layer $[4,14,15]$. Chips development is associated with the following:

1. the size of the shear plane angle $\phi_{1}$

2. created chips and their shape (continuous chips or chips containing elements connected by a deformed interlayer)

3. shear deformation development $\gamma_{s h}$ while the chips are being separated

4. shearing stress $\sigma_{s}$ and $\tau_{s h}$ acting on a shear plane 5. friction stress $\sigma_{f}$ and $\tau_{f}$ acting on the contact back surface - machined surface

6. "Ploughing effect" with the cutting edge radius of curvature $r_{p}$ - a cutting edge depending on the size $r_{p}$ in addition to shear effect acts as a graver to the machined surface

7. remperature generated in different sources

8. cutting conditions $\left(f, v_{c}, a_{p}\right)$

The summary of events associated with the chips development can be regarded as the summary of the causes that create the surface layer and check its status after the removal of the layer being cut geometrically by a certain cutting edge. When cutting by a geometrically indefinite cutting edge, the surface layer formation and its status are mainly due to the following $[16,17,18]$ :

1. microcutting, microcovering and microsmoothing by abrasive grains

2. deformation in front of abrasive grains

3. "Ploughing effect" for microcutting

4. a medium size of free and bound abrasive grains

5. the mean number of engaged abrasive grains

6.interactions during grinding

7.temperature distribution in the surface layer 8. transfer of the generated heat into the workpiece 9. cutting conditions $\left(v_{c}, v_{o}-\right.$ workpiece speed during grinding $\left[\mathrm{m}^{\mathrm{min}}{ }^{-1}\right], \mathrm{a}$ - width of the engagement during grinding [mm])

Unevennesses, which appear on the machined surface, in many cases have the characteristic arrangement, which is the result of mutual geometric and kinematic relations of a tool and a 
workpiece and is accompanied by some physical phenomena, such as plastic deformation, heat generation, and the like. According to the machining conditions, the type of a workpiece material, a tool material, this reflects on either the change in the nature of the surface, or the change of the surface layer properties [19,20].

Machining is a technological process which creates a new surface separating particles of the material by cutting in the form of chips[21]. Cutting is the process of plastic deformation, whose development is influenced by the properties of a machined material and the conditions under which it is performed. The most important of these conditions is a deformation rate and a temperature. Considering the surface, it is important to focus on the stage of plastic deformation when the material being cut is separated in the form of chips [22]. Chipsseparating is the last stage of plastic deformation, therefore it is possible to consider this phase as a form of fracture and the resulting surface as the fracture area. The type and nature of the fracture depend on the material being machined, its crystalline structure and the deformation conditions. The resulting fracture area must be considered in terms of load forces and stress acting at its formation, the required energy and the initial crack propagation rate as well as in terms of a fracture area morphology[23].

\section{Problem Solution}

Such a two-level factorial experiment has been used for a simple specification of the factors that statistically had a significant effect on the values variability of the Ra, Rz variables. An exact method has been applied to the investigation of a cutting conditions effect on the examined parameters of a surface roughness profile. In order to eliminate the potential influence due to the preference of one factor or a combination of factors on the expense of others, the mathematical plan of experiments was arranged in the way so that the experiments could be conducted in a randomized order. To the coded values of -1 and +1 levels, which represent the boundary of the investigated area of each factor, the levels real values (Tab. 1) were assigned. From a user's point of view, for the given case, cutting conditions, Tab 2, which affect the studied characteristics of the surface morphology were considered to be the factors (process parameters). In the Design of experiments theory they are called a response.

Table 1: Coded Factor Levels.

\begin{tabular}{|c|c|c|c|c|c|}
\hline с̌. & Factors & & & $\begin{array}{l}\text { Scales } \\
\text { factor: }\end{array}$ & f the \\
\hline & $\begin{array}{l}\text { denota- } \\
\text { tion }\end{array}$ & terminology & measure & -1 & +1 \\
\hline 1. & $x 1$ & $\begin{array}{l}\text { Cutting } \\
\text { speed }\end{array}$ & $m \cdot m^{-1}$ & 8,792 & 351,68 \\
\hline 2. & $\times 2$ & Feed & $\mathrm{mm}$ & 0,1 & 0,5 \\
\hline 3. & $x 3$ & $\begin{array}{l}\text { Depth of } \\
\text { cut }\end{array}$ & $\mathrm{mm}$ & 0,1 & 3,0 \\
\hline
\end{tabular}

Table 2: Coded conditionf of experiment

\begin{tabular}{|c|c|c|c|c|c|c|}
\hline \multirow[t]{2}{*}{ Run } & \multicolumn{3}{|c|}{ Coded conditions of runs } & \multicolumn{3}{|c|}{ Real conditions of runs } \\
\hline & $\mathbf{x 1}$ & $\mathbf{x} 2$ & $\mathbf{x} 3$ & $\begin{array}{l}\text { vc } \\
\mathrm{m} \cdot \mathrm{min}^{-1}\end{array}$ & $\begin{array}{l}\mathrm{f} \\
\mathrm{mm}\end{array}$ & $\begin{array}{l}a_{p} \\
m m\end{array}$ \\
\hline 1. & -1 & -1 & -1 & 8,792 & 0,1 & 0,1 \\
\hline 2. & +1 & -1 & -1 & 351,68 & 0,1 & 0,1 \\
\hline 3. & -1 & +1 & -1 & 8,792 & 0,5 & 0,1 \\
\hline 4. & +1 & +1 & -1 & 351,68 & 0,5 & 0,1 \\
\hline 5. & -1 & -1 & +1 & 8,792 & 0,1 & 3,0 \\
\hline 6. & +1 & -1 & +1 & 351,68 & 0,1 & 3,0 \\
\hline 7. & -1 & +1 & +1 & 8,792 & 0,5 & 3,0 \\
\hline 8. & +1 & +1 & +1 & 351,68 & 0,5 & 3,0 \\
\hline
\end{tabular}

The actual experiment was carried out under the conditions listed in Tab. 3.

Subsequently, as the conditions of normality of repeated measurements and homogeneity of variance of repeated testing for the presence of outliers had been verified, regression analysis was performed. Based on the analysis of the performed experiments, the mathematical-statistical model of a surface roughness with longitudinal turning was developed in the form of a power function:

$\hat{R} z, \hat{R} a=10^{b_{0}} * v_{c}^{b_{1}} * f^{b_{2}} * a_{p}^{b_{3}}$

the mathematical - statistical model of the examined roughness profile parameters can be specified in the form:

$$
\begin{aligned}
& \hat{R} z=\frac{10^{2.364( \pm 0.424)} * f^{0.787 \pm 0.397)} * a_{p}^{0.017( \pm 0.188)}}{v_{c}^{0.199( \pm 0.173)}} \\
& \hat{R} a=\frac{10^{1.775( \pm 0.343)} * f^{1.077( \pm 0.321)} * a_{p}^{0.040( \pm 0.152)}}{v_{c}^{0.162( \pm 0.140)}}
\end{aligned}
$$


Table 3: Experimental conditions

\begin{tabular}{|c|c|c|c|c|}
\hline Experiment Code & \multicolumn{4}{|l|}{ Rz.vc,f,ap - 12050.1} \\
\hline Used machine-tool: & \multicolumn{4}{|l|}{ SU 40} \\
\hline \multirow[t]{2}{*}{ Used cutting tool } & Holder & Cutting Blade & Cutting Material & $r_{\varepsilon}[\mathrm{mm}]$ \\
\hline & MWLNR & KNUX 190405 EL & P20 podla ISO & 0.50 \\
\hline Cutting Conditions & $\mathbf{v}_{\mathbf{c}}\left[\mathbf{m} \cdot \mathbf{m i n}^{-1}\right]$ & $a_{p}[\mathrm{~mm}]$ & \multicolumn{2}{|l|}{$f[\mathrm{~mm}]$} \\
\hline & $7.892-351.680$ & $0.10-3.00$ & \multicolumn{2}{|l|}{$0.100-0.500$} \\
\hline Set the tool to the workpiece axis & $\mathrm{h}=0[\mathrm{~mm}]$ & Cooling & \multicolumn{2}{|l|}{ No } \\
\hline Machined material & \multicolumn{4}{|l|}{12050.1} \\
\hline The measuring instruments & \multicolumn{4}{|c|}{ MitutoyoSurftest SJ - 301 to measure parameters of surface roughness } \\
\hline Accuracy of calculation & $E=1 / 1000$ & \multicolumn{2}{|c|}{ The chosen level of significance } & $a=0.05$ \\
\hline The number of & $N=8$ & \multicolumn{2}{|c|}{ The number of repeated measurements for each experimental unit } & $m=5$ \\
\hline
\end{tabular}

\section{Results and Discussion of Achieved Results}

The analysis of factor effects on the total value of the investigated roughness profile parameters confirms the conclusions of previous experiments, where the effect of cutting conditions on the parameters was examined. More detailed effects of individual factors (cutting conditions within the used intervals) are shown in figures $5-10$.

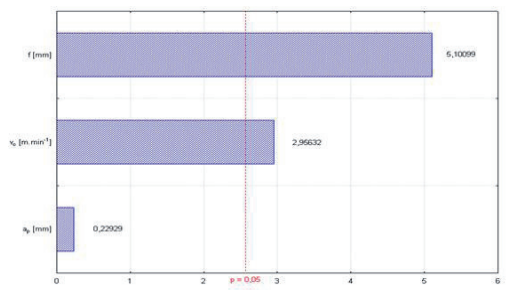

Fig. 1: The Pareto diagram of the cutting conditions effect on the Rz value.

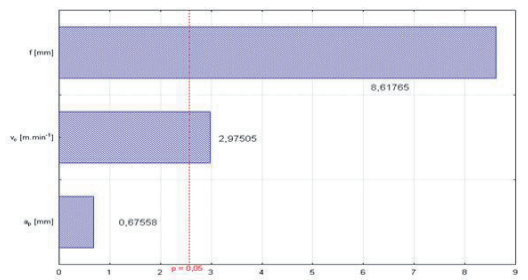

Fig. 2: The Pareto diagram of the cutting conditions effect on the Ra value.

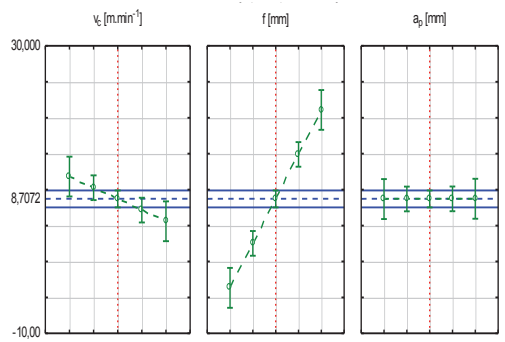

Fig. 3: The factor effects on the resulting value $R a$.

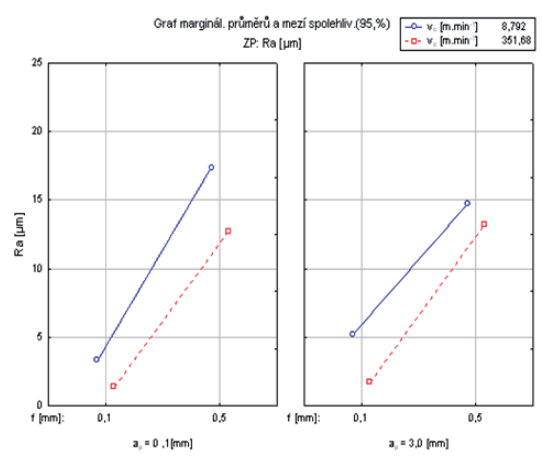

Fig. 4: Graph of cutting conditions effect on Ra.

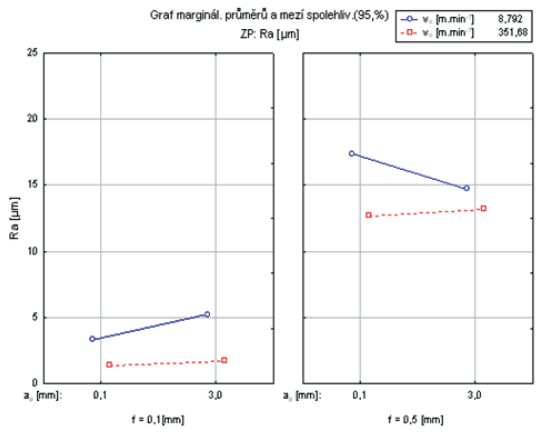

Fig. 5: Graph of cutting conditions effect on Ra.

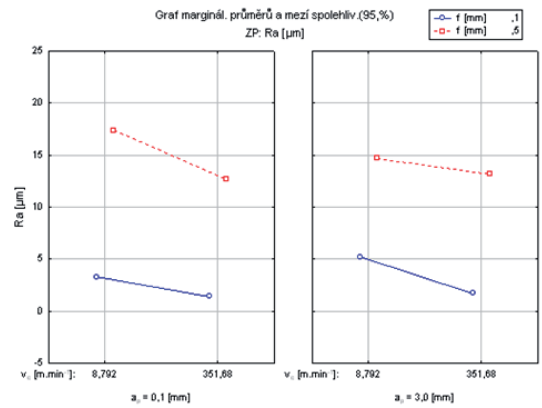

Fig. 6: Graph of cutting conditions effect on $R a$. 


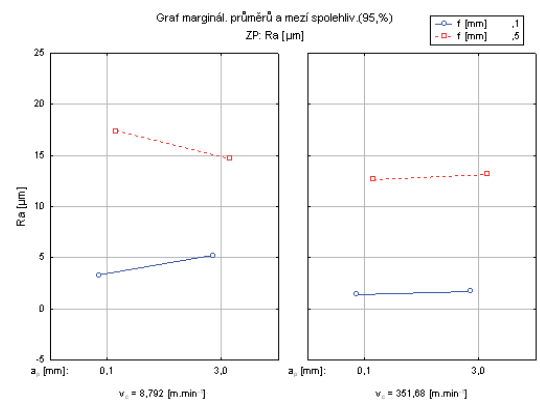

Fig. 7: Graph of cutting conditions effect on Ra.

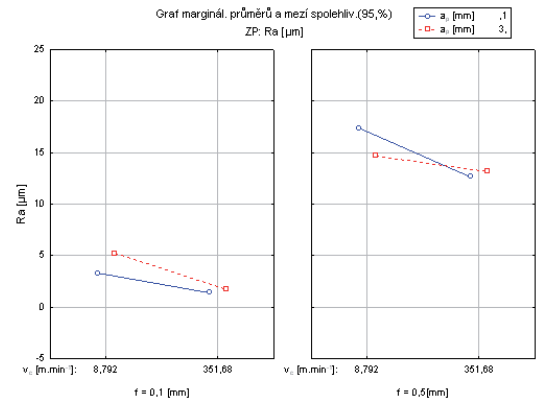

Fig. 8: Graph of cutting conditions effect on $R a$.

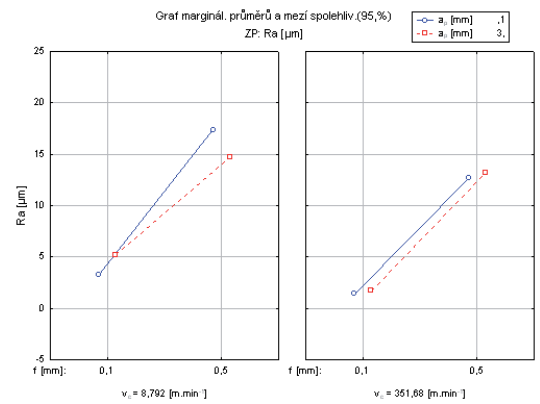

Fig. 9: Graph of cutting conditions effect on $R a$.

From the above graphs and performed analysis while evaluating individual experiments conducted by the method of the planned experiment follow the conclusions: based on Fig. 5. And Fig. 6 it can be stated that throughout the entire range of feed, increasing its values increases the conditioned value of the investigated parameter $\mathrm{Ra}$, and this increase is more significant in the lower limit of the selected range of cutting speeds. In the range of small feeds (a lower limit of the selected interval), there is a slight increase in the investigated Ra parameter due to the increase in the value of the cut depth and this increase is more significant with low cutting speeds.
At the upper limit of the selected interval of feed, increasing the cutting depth at low cutting speed causes a decrease in the value of the parameter Ra. In both boundary areas of the selected interval of the cutting depth based on Fig. 7 it can be seen a decrease in the investigated parameter values due to the increase in cutting speed values, while the increase in feed rate values causes the growth of this value. A slight increase in the value of the examined parameter Ra occurs due to the increasing depth of the cut to the upper limit of the interval used, whereas this change is more evident in small feeds area. In the area of the upper limit of the selected interval of cutting speeds, this development can be considered constant. Fig. 8 and Fig. 9 confirms the previous findings. While increasing the cutting speed, the conditional values of the investigated parameter Ra decrease, while in the upper limit area of the selected feed interval, higher values of Ra are achieved. The decrease in the value of the examined parameter of the roughness profile in this area when using small depths of cut is more significant.

\section{Conclusion}

Based on the above calculations it can be concluded that the feed and cutting speed have the greatest impact on the studied parameters Rz and Ra to. Based on the mathematical - statistical models for the identification of relations between cutting conditions and the studied parameters of a roughness profile, it is possible to draw conclusions concerning the values of optimization parameters that are consistent with the results of statistical optimization.

- statistically insignificant effect on the studied parameters of a roughness profile has a depth of cut, which is evident from the previous calculations, and graphs development,

- the feed /shift impact was the most significant, while the cutting speed is insignificant in the area of a calculated optimum,

- the effect of a cutting speed on the examined parameters in the range of applied values has been proven,

a combination of high cutting speeds, small feeds and small depths of cutting appears the most advantageous,

- increase in the depth of cut results in a slight increase in values of the studied parameters,

- an average value of machining time effect on the value of the unevenness maximum height of a pro- 
file roughness is $16 \%$, while the share of other operating factors is $84 \%$,

- the overall impact of cutting conditions on the examined parameters for the roughness profile $\mathrm{Ra}$ and $R z$ represents $37 \%$ with $R z$ and $49 \%$ with $R a$; the difference being due to a smaller range of the Ra values within the used cutting conditions,

- the influence of other operating factors - characteristics of the workpiece material, tool geometry, tool wear, cutting forces acting, etc. - 63\% with $R z$ and $70 \%$ with $R a$,

- the influence of a cutting speed on the total value of $R z$ is $13 \%$, while neglecting the other operating factors its impact is $36 \%$ and the influence of the speed on the Ra value is $12 \%$, eventually $24 \%$ when neglecting the other factors,

- the impact of the feed on the overall value of the unevenness maximum height of the roughness profile is $23 \%$, eventually $61 \%$ when neglecting the other operating factors, while the impact of the feed on the total value of the arithmetic mean deviation of the roughness profile is 34\%, eventually $70 \%$,

a combination of high cutting speeds, small feeds and small depths of cut appears to be the most advantageous,

- impact of the feed on the total value of the arithmetic mean deviation of the roughness profile is $34 \%$, eventually $70 \%$,

- a combination of high cutting speeds, small feeds and small depths of cut appears to be the most advantageous.

\section{Acknowledge}

The authors express their sincere thanks to Slovak Ministry of Education, Science, Research, project KEGA 049-TUKE- 4/2012 and project VEGA No. 1/ 0396/11.

\section{References}

[1] Bátora, B.- Vasilko, K. Obrobené povrchy, technologická dedičnost', funkčnosț. Trenčín: Trenčianska univerzita, 2000, $183 \mathrm{~s}$.

[2] Békés, J.: Inžinierska technológia obrábania kovov. Bratislava: ALFA 1981, 400s

[3] Békés, J. - Andonov, I.. Analýza a syntéza strojárskych objektov a procesov. Bratislava: ALFA, 1986, 376 s. 1. Vyd.

[4] Beňo, J.: Teória rezania kovov. Košice: Strojnícka fakulta TUKE, 1999, $255 \mathrm{~s}$.

[5] Buda, J. - Békés, J: Teoretické základy obrábania kovov. Bratislava: ALFA, 1977, $682 \mathrm{~s}$
[6] Bumbálek, B. - Odvody, V.- Oštadal, B.: Drsnost povrchu. Praha: SNTL, 1989, 330 s.

[7] Kažimír, I. - Beňo, J.: Teória obrábania. Bratislava: ALFA, 1989, $280 \mathrm{~s}$.

[8] Vasilko, K. Technológie zmeny rozmerov. Prešov: FVT TUKE so sídlom v Prešove, 2004, 315 s.

[9] Vasilko, K.: Tribologické vztahy medzi nástrojom a obrobkom pri dokončovaní povrchov. Výrobné inžinierstvo, 2003, roč. II, č. 4, s. 9-11.

[10] Vasilko, K.: Deformačné štruktúry pri obrábaní kovovl In: Medzinárodná vedecká konferencia Funkčné povrchy, 27. - 28. Máj 2004, Trenčín: Fakulta špeciálnej techniky, 2004, s. 200-208.

[11] Vasilko, K. - Vasilková, D.: Nové geometrické vztahy medzi rezným nástrojom a obrobkom a ich vplyv na mikrogeometriu. Výrobné inžinierstvo, 2002, roč. I., č. 2-3, s. 29-34, ISSN 1335-7972

[12] Balara, M. - Broržíková, J.: Zrýchlené skúšky spolahlivosti elektronických zariadení. In: Výrobné inžinierstvo, Roč. 3, č.2, 2004, s. 75-78. ISSN 1335-7972.

[13] Pitel, J.: Model of the heated space for heating process control using. In: Matematičeskije metody $\vee$ technike i technologijach. Voronež:Voronežskaja gosudarstvennaja technologičeskaja akademija, 2006, p. 141-143. ISBN 5894484316

[14] Bátora, B.: Význam technologickej dedičnosti obrobených povrchov $\vee$ spolahlivosti výrobných strojov a zariadení. Výrobné inžinierstvo, 2004, roč. III, č.1, s.10 - 14, ISSN 13357972.

[15] Bátora, B.: Metrológia obrobených povrchov. In: Medzinárodná vedecká konferencia Funkčné povrchy, 27. - 28, máj 2004. Trenčín : Fakulta špeciálnej techniky, 2004, s. 25 $-33$.

[16] Bilík, O.: Obrábění II - 1. díl, Fyzikálně mechanické záležitosti procesu obrábění. 2.vydání. Ostrava : FS VŠB - TU Ostrava, 2000.138 s. ISBN 80-7078-228-5.

[17] Blaščík, F., et al. : Technológia tvárnenia, zlievarenstva a zvárania. Bratislava: ALFA, 1988, 832s. 